\title{
PERSPECTIVE AXIOLOGIC-INTEGRATOARE FORMATOARE ALE EVALUĂRII ȘCOLARE. UN DEMERS APLICATIV
}

Lect. Univ. Dr. Emil Lazăr

Motivația alegerii temei și imperativul acestei tratări au fost determinate de căutarea răspunsului la întrebarea ce se evaluează la ora de Religie. O oportunitate aparte a reprezentat-o și dorința de a pune în acord problematica Educației religioase cu abordarea contemporană a educației și a evaluării în educație: educație permanentă, pentru valori, autoformare, devenire, interiorizare, dezvoltarea naturii umane, evaluare autentică. Se încearcă o perspectivă constructivă asupra Educației religioase (autentică), a utilității acesteia pentru formarea și dezvoltarea omului, în condițiile în care aspectul utilizant al Religiei ca disciplină școlară pentru axiologia și comportamentul omului este dovedit, deși valoric nu este făcut manifest.

\section{Abstract:}

The motivation for the choice of theme and the imperative for this paper have been determined by searching for an answer to the question what should we evaluate at Religion classes? A rare opportunity has been also the desire to put the issue of the religious education in line with the contemporary complex approach to education and 
assessment: lifelong education, education striving for values, competence, becoming, internalization, development of human nature, authentic assessment.

Therefore, this paper is an attempt to do research on assessment in religious education, from the point of view of the purpose, the objectives of this school subject. The significance and reason for choosing the theme are given by the constructive perspective which the authentic religious education may have for the human training and development. The practical dimension of Religion as a discipline for the human axiology and behaviour is proved, though valuably is not made manifest.

Cuvinte-cheie:

valoare, Educație religioasă, evaluare formativă, integrativ, integrator

\section{Abordări axiologice și metodologice ale Evaluării}

\section{1. „Valoare” si „Evaluare”}

Atribuirea unui grad de utilitate sau oportunitate unui obiect, unei acțiuni sau atitudini definește conceptual ideea de „valoare". Valoarea este unul dintre cele mai importante criterii de socializare ale omului, definind sistemul de opțiuni al fiecăruia sau al grupului. În spațiul interacțiunii umane, valoarea este criteriul dominant de raportare și calificare. Ea determină scopul individului, mijloacele de realizare și strategiile de preluare a efectelor atingerii unui scop.

Din această perspectivă este interesant de apreciat raportul dintre valoare și alte concepte-deziderate umane: rațiune, libertate, ideea de sacru, dar și contextul apariției și analizei lui:

"Ce este „valoarea"? Ce raport există între valoare și raționalitate, valoare și libertate, valoare și dorință, valoare și sacru? În ce sens se poate vorbi despre un sistem sau o scară (ierarhie) a valorilor? Există valori universale, identificate transcultural? Care ar putea fi locul unei reflecții asupra valorilor în teoria educației? Poate Școala să transmită (învețe) valori? Există valori proprii Școlii și ce trebuie să înțelegem prin valorile educației?" (Olivier Reboul, Les valeurs de l'éducation, 1992, în D. Hameline, Revue française de pédagogie, 1993, nr. 103, p. 109).

Valoarea, ca raportare motivantă, caracterizează alegerea unei alternative implicante din mai multe posibile, iar ca stare emotivă localizează și o măsură subiectivă. Individul poate nu numai să discearnă valori, dar și să le ordoneze calitativ. Distincția fapt-valoare se află în 
miezul dezbaterilor epistemologice asupra posibilității obiectivitătii în stiinte şi nu numai.

Alegerea, valoarea, ordonarea, raportarea conduc înspre evaluare.

Evaluarea reprezintă o acțiune managerială proprie sistemelor socioumane care solicită raportarea rezultatelor obținute într-o anumită activitate la un ansamblu de criterii specifice domeniului în vederea luării unei decizii optime, (Cristea, 1998:203).

Alteori, evaluarea poate avea rolul de a „redefini mijloacele care să fie utilizate pentru atingerea obiectivelor sau chiar a redefini anumite obiective conform cu rezultatele cercetării", (Bigman, 1961, apud G. Mățăuan, 1995).

Într-un context specific domeniului în discuție, pedagogul D. Lawton afirma că „decizia privind evaluarea implică valori” (Lawton, 1981:187). El aborda momentul evaluării, ca etapă a demersului pedagogic, proces complex, desfășurat în timp, fiind necesar pentru alte trei trăsături specifice: „evaluarea are ca funcție să furnizeze informații asupra succesului sau eșecului probabil al programelor educative (sau al persoanelor); această informație este sau ar trebui să fie utilă ca bază a luării de decizii în educație; deciziile educative ar trebui luate într-un context mai larg decât școala sau instituția educativă" (Lawton, 1981:16).

Ceea ce interesează în tratarea celor două concepte este perspectiva comună a aprecierii, care înseamnă din perspectiva "valorii" recunoaștere, iar din cea a „evaluării”, analiză. Aceste două perspective sunt dorite a fi direcțiile de tratare a evaluării în educație sub aspectul său apreciativ-calitativ.

1.2. Conceptualizarea evaluării în educație. Scurt exordium

Pornind de la examinare și notare, s-a ajuns la înțelegerea evaluării ca activitate complexă de cunoaștere și „de formulare de judecăți de valoare despre procesul și produsul învățării elevilor" (Manolescu, 2010:17). Tranziția s-a făcut de la obiectivul principal, acela de a efectua un studiu sistematic de practici de examinare și, mai general, de evaluare, la evidențierea rolului și importanței diferiților factori (Abernot, 1996:59) care pot afecta rezultatele, la „emiterea unor judecăți de valoare (care enunță o apreciere, n.n.) cu caracter integrator, în funcție de anumite criterii precise, prestabilite, cu scopul de a stabili 
eficiența/eficacitatea unor acțiuni, procese, care să conducă la luarea unor decizii educative, cu implicații pozitive pentru dezvoltarea personală, instituțională școlară și socială" (M. Opriș, 2010:17). Evaluarea poate fi înțeleasă în lumina citatului anterior ca aprecierea a randamentului din perspectiva rezultatului unei acțiuni, dar și ca apreciere a valorii, productivitate, operativitate.

Așadar, evaluarea în educație s-a aflat și, în continuare, se află în procesul de transfer de la analiza componentelor implicate („preocupare față de măsurarea și aprecierea valorii rezultatelor învățării" (Manolescu, 2010:19), la înțelegerea logicii care guvernează procesul didactic („explicarea proceselor de învățare și de predare”, M. Manolescu, ibidem).

Cunoașterea (și aprofundarea) mecanismului/mecanismelor demersului evaluativ face trecerea la Teoria și Metodologia Evaluării.

Aflată sub lupa cercetărilor pedagogice, ca Teorie a Evaluării, evaluarea școlară, etapă și proces importante ale demersului didactic, a beneficiat de "schimbare”, "transformare”, "transpoziție”, „transfer”, astfel încât "proba de încercare”, evaluarea, criteriul, rezultatul notării au devenit componentele unui proces în a cărui analiză ele contează sub aspectul ameliorării, îndreptării programului educativ și al dezvoltării ulterioare a elevului. De aceea, achizițiile, progresul școlar, implicațiile în social sunt valori urmărite de Teoria Evaluării.

Nu doar ce? și de ce?(conținut), ci cum? și pentru ce? (proces).

Practica evaluării dovedește că Teoria Evaluării este "supraordonată" docimologiei, mai exact evaluării docimologice. Asistăm la o „metaordonare” în sensul integrativ (acela că întregește, completează) și integrator (acela că armonizează diverse elemente, structuri în ansamblul procesului și se include) al cuvântului.

Componenta axiologică a Teoriei și Metodologiei Evaluării (în sensul emiterii de judecăți de valoare prin actul evaluării), complexitatea ca proces (în sensul abordării domeniilor cognitive, afective și comportamentale), întrepătrunderea (perihoreza) dintre procese (alături de cel de predare și de învățare), precum și raportarea contribuției fiecăruia dintre procese în explicarea rezultatelor obținute în evaluare, funcția de feedback (retroacțiune), dominantă în domeniul comunicării 
și informării, dar și al ameliorării, optimizării și intervenției sunt specificitățile și prioritățile care fac din Teoria și Metodologia Evaluării o ramură pedagogică de dată recentă, dar cu istoricitate, cu o metodologie proprie și domenii de competență care se doresc a fi explorate.

Astfel, asistăm, așa cum remarcau, într-un studiu colectiv cercetători americani din domeniul cercetării educaționale și paradigmatice, la interesul crescând referitor la statutul și poziția cercetării calitative in educație în contextul unei analize, de la dezbaterea cu multiple voci privitoare la paradigmele cercetării educaționale, la cercetarea cantitativă și statistică promovată ca standard de instituțiile guvernamentale de cercetare educațională (Handel, Lather, 2006:2). Dar și la corelarea dintre paradigmele reprezentate de lumea cercetării educaționale și procesul de elaborare a politicilor publice.

1.3. O posibilă Metodologie a cercetării în Evaluarea școlară

Gilbert de Landsheere vede idealul în evaluarea școlară ca fiind „(o evaluare) mai exactă din punct de vedere științific și mai echitabilă din punct de vedere moral" (Landsheere, 1975).

În termeni de cercetare științifică, atât profesorul, cât și elevul sunt influențați de numeroase variabile: de la formația inițială, sensurile și semnificațiile pe care le conferă finalităților educației (definiția pe care o dă), până la părerile colegilor, competiția în care se află disciplina pe care o predă în raport cu alte discipline de învățământ și cuprinse în catalog-în cazul profesorului și de la reprezentarea pe care o au elevii în ceea ce îi privește pe profesorii lor, ce, de altfel, joacă rolul de mediator al transformărilor suferite de curriculum-ul formal în mediul școlar, și până la ideea de „evaluare urmărită utilitarist și pragmatic” (se urmăresc doar disciplinele din examenul de final de ciclu (evaluare sumativă), cel care dă accesul într-un ciclu superior!).

André Levy, profesor de psihologie socială la Universitatea din Paris, preocupat fiind de modul cum se realizează transpoziția în procesul evaluării, afirma că „procesul de evaluare rezultă ca efect al unei operații mentale de simplificare și de reducere și se traduce ca acordare a unei note unice, care este rezultatul unui compromis arbitrar între evaluările mai multor calități de ordin diferit. (...) Acest proces, comun în toate domeniile, este deosebit scos în evidență în educație. 
Astfel, un student va fi judecat diferit dacă luăm în considerare participarea sa, seriozitatea muncii sale, eforturile sale pentru progres, comportamentul său turbulent sau mai concentrat în clasă, ușurința de vorbire, inteligența sa, activitatea sa, și bine, ... rezultatele sale la diferite discipline.

Cu cât se apropie de lumea profesională și înțelege mai bine locul său în ierarhie, poziția sa în raport cu alți elevi indică „valoarea” sa pe piață.

Pentru a determina acest lucru trebuie să stabilim o pondere între diferitele criterii (nu se pot ocupa două locuri în același timp). Modul în care se face această pondere este într-o anumită măsură la latitudinea profesorului, dar marja este îngustă, în mare măsură determinată de sistemul de valori care predomină în societate și în școală, în special. Astfel, fiecare elev este încadrat și identificat cu locul său în clasă (în înțeles material) și tinde să se identifice cu el însăși. (...) Consecințele unor astfel de etichetări sunt deosebit de importante, încât acest loc va fi dificil de schimbat de-a lungul carierei sale de elev, deoarece influențează hotărârile luate despre el ulterior de alți profesori și confirmă adesea comportamentul său". (trad. n.)

Din perspectiva celuilalt actor implicat în procesul evaluării, evaluatorul, este important rolul și funcția pe care o alege în mod pregnant: pentru evaluarea formativă, realizată pe întregul parcurs al activității didactice, centrată pe elev, în care profesorul încurajează (feedback direct și constructiv, de schimbare), sprijină, „compară performanța elevului cu un prag de reușită stabilit dinainte" (Meyer, 2000:25), cu funcție de reglare, informare și confirmare, ameliorare, de susținere a efortului de autoevaluare (Manolescu, 2010:62), dar și pentru evaluarea formatoare, în care devine facilitator al învățării, sugerează (utilizează ascultarea activă, comunicarea eficientă, verbul „a învăța” în locul verbului „,a memora"), iar elevul este conștient de necesitatea atingerii criteriului de reușită și de produs (ibidem). Trebuie evaluate toate componentele unui rezultat al învățării (cunoștințele, abilitățile, competențele), nu numai cunoștințele!

2. Educația religioasă, dimensiune a educației integrale, integratoare a valorilor umane 
Rămânând în sfera valorilor, a lăuntricului, admițând importanța trăirilor religioase, este important să distingem între cele trei capacități ale omului pe care teologia le prezintă ca „puteri sufletești”: rațiunea, voința și sentimentul (afectivitatea) și pe care psihologia le traduce cognitiv, volitiv, afectiv. Ele generează, prin problematicile puse în discuție, domenii de studiu, de la cel sistematic, până la cel istoric sau practic, în care sunt abordate realitățile existenței dihotomice (psihosomatice) a omului, „relațiile” existente în această „coabitare” a sufletului în trup, dimensiunea temporală circumscrisă, hic et nunc (imanentă) sau cea transcendentă, eshatologică.

O abordare care ajută analiza corectă a complexității umane din perspectiva valorilor este definirea teologică a omului ca persoană și nu ca individ. Persoana („prosopon” în lb. elină) este cea „chemată” să dezvolte „puterile sufletești” pentru ca, după scopul vieții creștine, să ajungă a fi ,,întocmai (asemenea) cu Dumnezeu (după har), dar nu alt dumnezeu”, să își împlinească rostul, „destinul lui etern” (Garrido, 1995), de înălțare, de „chemat la mântuire” (D. Stăniloae, 1996).

Omul, ca persoană își urmează predispoziția lăuntrică și îndemnul la căutare, în continuu dialog cu ceea ce este exterior lui sau cu propria conștiință. Grație acestui tip de dialog, omul ajunge la descoperirea sau regăsirea lăuntrului lui (eul interior), a propriilor trăiri afective (cum ar fi religiozitatea) (D. Opriș, Bocoș, 2004:6).

Vorbind despre personalitate, omul are nevoie de formarea propriei personalități (identități), aici intervenind înrâurirea educației sub toate formele sale (teologia vorbește de „existența sufletului uman, care poate fi modelat prin educație") (Șebu, Opriș, Opriș, 2000:21).

Educația este inclusă în sistemul valorilor care orientează omul în demersurile de formare și dezvoltare a propriei personalităti. Corelate personalității, sunt caracterul și conștiința, formabile și educabile prin activități cognitive sau afective. Se recunoaște, de pildă, că există o învățare de tip afectiv, care constă în dezvoltarea caracterului și conștiinței, a atitudinilor și valorilor (Bloom, 1970, apud Cucoș, C., Labăr, A., (2008), Consecințe ale educației religioase asupra formării conduitelor tinerilor. Perspectiva beneficiarilor. În: Basileia, vol. I, nr. 1-2, 
p. 61). Valorile religioase țin de domeniul afectiv, iar în absența lor, procesul de formare a personalității ar fi unul incomplet, limitat.

Este, așadar, o pledoarie pentru Educația religioasă ca dimensiune a educației integrale (apud C. Cucoș), dar și integratoare.

Vorbind de Educație religioasă, trebuie să distingem între educația oferită de școlile publice (de Stat) și cea care specializează, oferită de școlile confesionale, aflate sub patronajul total sau parțial al Instituțiilor de cult/ bisericești. Iar aceasta este o altă nuanță în favoarea Educației religioase.

„Noi toți avem nevoie, în procesul de formare și modelare a propriei personalități, de recurs la religie și de o minimă inițiere în problematica acesteia" (M. Opriș et al., 2004:7) se afirmă într-o cercetare pedagogică în domeniul Educației religioase, lăsându-ne să înțelegem că recursul la religie inițiază, în vreme ce educația religioasă confirmă, poate transmite cunoștințe și forma competențe într-o manieră sistematică.

Încadrarea didacticii disciplinei Religie ca parte a didacticii generale în formarea inițială a cadrelor didactice ale acestei specialități ne îndreptățește să promovăm denumirea de Educație religioasă pentru un anumit cult sau confesie. Aici se poate nuanța pentru că domeniile, unitățile de conținut nu sunt aceleași și nici la fel formulate de către toate cultele religioase sau confesiile creștine.

\section{Aspecte ale evaluării formative în Educația religioasă}

\subsection{Analiză critică a evaluării la Religie - perspectiva valorii}

A analiza înseamnă a face o cercetare atotcuprinzătoare, sistematică, prin care obiectul sau subiectul cercetat este descompus în părțile sale, iar acestea sunt ordonate, cercetate și evaluate. Sunt importante de observat conexiunile dintre elemente si integrarea lor, ca de altfel și funcțiile, limitele, derivatele și aplicațiile lor (Dictionarul Explicativ (1993-2009)). 
Așadar, vorbim despre o modalitate de investigare prin diverse procedee, despre evidențierea articulațiilor reciproce ale elementelor și descrierea traiectoriei ce caracterizează dinamica de ansamblu a obiectului considerat (analiză funcțională și sistemică), despre interpretarea științifică a elementelor constitutive (analiză critică de conținut), ordonarea acestora.

Dacă ar fi să vorbim despre o „critică a evaluării în disciplina Religie", (critică sistemică, de analiză și cunoaștere, care să contribuie efectiv la aprofundarea punctelor de vedere) trebuie să considerăm toate "faptele pedagogice" sau diferitele "fapte pedagogice corespunzătoare proceselor educaționale parcurse" în studiul acestei discipline de învățământ.

Întâi de toate trebuie să remarcăm că „raportul dintre educație și valorile religioase se întemeiază pe educația axiologică, educația pentru/prin valori și pentru/prin valorizare" (Cucoș, 2009), apoi să acceptăm faptul că „dimensiunile/laturile pedagogică și psihologică în câmpul educației sunt, practic, inseparabile" (Opriș, Opriș, Bocoș, 2004:19).

$\mathrm{Nu}$ în ultimul rând, este necesară identificarea "zonelor de tangență între creștinism și educație" în sensul sinergiei dintre „realitățile psihologice religioase și rolul unei educații intelectualreligioase" (M. Manta, prefață la Pr. M. Bulacu, 2009).

Un alt domeniu de discutie ar putea fi aspectul formativ adus de Educația religioasă, ca specificitate: deplasarea accentului de la latura informativă („transmiterea de idei gata făcute” (Timiș, 2004:17) la dimensiunea formativă (care, în opinie personală, consacră denumirea de educație religioasă dată disciplinei de studiu Religie).

Considerăm că, în contextul educației pentru valori, valorile religioase se pot transmite și învăța, așa cum exisă un dat obiectiv și ontologic constituit de predispoziția sufletească de a trăi după „valori”, în general, și, în plan religios, specific, a primi și a transpune valori religioase. Educația este „vehiculul" prin care valorile religioase se pot împropria sau transmite.

George G. Antonescu (1946:23), vedea „religia utilă în educarea sentimentelor", după o metodă liberă, „autodeterminarea prin 
convingere, singura care poate realiza disciplina liberă" (apud I. Albulescu, Curs).

Valoarea experimentului propus de G. G. Antonescu stă în considerațiile pe care le aduce în contextul evaluării în Educația religioasă, acelea ale valorii date volitivului prin educație. Este bine de precizat valența formatoare a evaluării identificată în încercarea lui G. G. Antonescu - de altfel, un promotor al self-development-ului: coresponsabilizarea celui care învață de efectele schimbării propuse.

Consecvent, autorul propune, în educația religioasă, o viziune în care evaluarea este văzută ca un factor de reglare și optimizare (idem, 2003, p. 12).

Dacă termenul propriu de evaluare în Educația religioasă apare la V. Timiș, ideea clar definită aparține lui Dorin Opriș și Monicăi Opriș, cu contribuția substanțială a Mușatei Bocoș. Ei sunt cei care aduc în contextul cercetărilor pedagogice Educația religioasă, iar ca delimitare, subliniază „problema delicată a evaluării la Religie” (Opriș, Opriș, Bocos, 2004:18).

Preocupări în domeniul Educației religioase întâlnim și la E. Popescu și C. Cucoș, ultimul, alături de A. Labăr, aplecându-se asupra consecințelor Educației religioase din perspectiva beneficiarilor (elevilor și nu numai), (Cucoș, Labăr, Consecințe ale educației religioase, în Basileia, 2008, nr. 1-2), afirmând că "formarea este un act de iubire", (Cucoș, 2008, b: 17).

Reafirmând chipul uman în virtutea (chemării la) asemănării cu Divinitatea, C. Cucoș pune, într-un alt context, mai plenar, „educația” în relație cu „iubirea, edificarea, desăvârșirea”, pentru că „despre ce este educația și cum se face ea aflăm (...) prin diferitele prilejuri de viață" afirmând „culturalizarea religioasă ca o coordonată a învățământului românesc" (Cucoș, 2008, b: 11).

Cu siguranță, vorbind despre „o critică” a evaluării, (în sensul articulării unor opinii în urma analizei) intrinsecă, de altfel, abordării Educației religioase în cercetările pedagogice actuale, rămân multe de spus, la fel cum alte multe nume pot fi enumerate ca preocupate de problematică. 
Prezentarea preocupărilor din cercetarea pedagogică făcută mai sus ar putea constitui și posibile răspunsuri la întrebări referitoare la funcțiile și operațiile evaluării în Educația religioasă:

Ce evaluăm la Religie sau ce ar trebui să evaluăm la Religie, achiziții cognitive, volitive sau afective?

Ceea ce evaluăm este ceea ce învață elevul în timpul orei de Religie sau ceea ce crede?

Cât de mult pot fi operaționalizate obiectivele în Educația religioasă?

(Dacă) pot fi „măsurate” faptele credinței?

Trebuie avută în vedere relația dintre „credință" - ca valoare - și comportament? (Dacă da, atunci ce metode și instrumente se folosesc în evaluare?)

Stabilim criterii de departajare a elevilor la ora de Religie (și din ce perspective)? Facem clasamente în funcție de ce criterii?

Ce consecințe (în sensul de impact, cui prodest?) există asupra elevului în urma evaluării la Religie?

În același timp, aceste întrebări pot constitui domenii de cercetare a demersului evaluativ în Educația religioasă, începuturi care să redefinească aspecte structurale ale acestei discipline de învățământ (denumire, curriculum, teoria și metodologia instruirii, teoria și metodologia evaluării).

3.2. Realizarea evaluării în Educația religioasă, posibile abordări

Evaluarea în Educația religioasă ar putea fi realizată doar în acord cu valorile religioase sau strict după metodologia evaluării?

Este mai cuprinzătoare, sub aspect pedagogic, o abordare integrată? 
Pornind din perspectiva valorilor religioase, sunt importante și relevante răspunsurile la o parte dintre interogațiile anterioare.

Privită doar ca etapă a procesului didactic, evaluarea poate să ridice următoarea întrebare: ce elementele proprii metodologiei evaluative (funcții, strategii, obiectul evaluării, operații și criterii, metode, tehnici, instrumente) îi sunt specifice educației religioase?

Problemele ridicate de învățarea (însușirea) valorilor religioase și formării atitudinilor ce decurg din acestea duc înspre ideea de reconsiderare a demersului didactic în Educația religioasă.

În acest sens, sunt destule voci critice:

"Suportul de predare, programele și manualele școlare, prezintă disciplina Religie într-o maniera ermetică, închisă, confesională, (...), calchiind practic conținuturile unor programe și manuale care încă se mai predau în școlile teologice ortodoxe din Romania. Predarea Religiei în această manieră și după asemenea „surse" nu poate avea - și nu are în realitate - alt efect asupra elevilor decât îndoctrinarea prost disimulată, supra-saturația catehetică și „dresajul ritual”. (Memelis, 2012).

Regândirea demersului evaluativ în Educația religioasă, o încercare de ghid al evaluării, ține de faptul că învățarea valorilor religioase reprezintă un proces complex, dinamic și de durată.

Afectivul nu poate fi "tradus" și, implicit, progresul în domeniul afectiv nu poate cuantificat, iar achiziților afective nu li se pot atribui valori, corelări. Ceea ce li se poate „vedea” este „efectul indirect, potențial, îndepărtat" (C. Cucoș, Labăr A. 2008, art.). În educația religioasă elevul poate, „cunoscând și conștientizând propria cunoaștere", să își transpună lui mai întâi, apoi să facă manifest, observabil prin comportament, o convingere, o credință, un crez, o valoare.

Dintr-o altă perspectivă, este necesar un timp pentru ca, de la nivelul cognitiv la care i se transmite elevului o noțiune sau concept, ele să poată fi, urmare a trăirii lăuntrice, a validării cu alte conduite, personale sau aparținând altora, împropriate, traduse în convingeri și să devină comportamente.

Așadar, „credința religioasă presupune astfel de componente, iar acestea nu se pot măsura și identifica în mod direct și imediat" (ibidem). 
De aceea, considerăm că este unilaterală, deloc cuprinzătoare și periculos (subiectiv) aplicată abordarea evaluării din perspectiva valorilor religioase, cel puțin în învățământul de Stat, în școlile publice. Am putea acorda circumstanțe atenuante unei asemenea abordări în Școlile confesionale, care au alte scopuri ale Educației religioase promovate, cu finalități ce trebuie să contureze formația teologică și practic-aplicativă profesională a viitorilor clerici. Dar nici aici nu pot fi utilizate metode și instrumente evaluative pentru un misticism care, într-o lume laică în continuă prefacere, nu ar fi înțeles.

Rămâne foarte importantă acceptarea specificității date Educației religioase de complexitatea ființei umane, precum și, la fel de importantă, răbdarea pentru analiza și înțelegerea, în context sau aparte, a resorturilor care generează trăirile, de la interiorizarea lor și până la facerea lor manifestă, care, la momentul evaluării, prin corelare, să arate, valid și fidel, un rezultat care să producă schimbare.

Un dispozitiv și o metodologie de evaluare care să fie aplicate Educatiei religioase?

Este la fel de extremă ca măsură, deși Educația religioasă posedă poate, mai mult decât alte discipline de învățământ, structura și conceptele cu care procesul evaluativ să fie unul propriu și eficient.

Gabriel Liiceanu analiza impactul pregătirii psihopedagogice a profesorilor de Religie și atrăgea atenția că, „dacă un profesor de matematică e slab pregătit, unul de biologie sau de fizică, urmările nu sunt pe o viață întreagă. Dacă un profesor de Religie nu este în regulă, nu are harul didactic și nu are cunoștințele pedagogice și cum anume să facă din predarea religiei un fapt pozitiv, se poate ajunge la mutilări pe viață, dar nefiltrarea la nivelul exigențelor pedagogice a calității profesorilor de Religie poate să fie dramatică. Nu e de joacă! Este unul dintre cele mai fine instrumente cu care se lucrează asupra psihicului și a mentalului uman. Drept care, răspunderea pe care v-o luați în clipa în care atestați calitatea unui profesor de Religie este enormă. (http://www.hotnews.ro/stiri-esential-17476758-dezbatere-desprereligia-scoli-gabriel-liiceanu-despre-cum-facut-patriarhia-guvernulping-pong-secretariatul-pentru-culte-functie-religia-ministruluiculturii.htm) 
Considerăm, așadar, că o viziune integrată, respectând specificitățile ca disciplină de studiu, dar și abordarea metodologică, cea care o face împreună-existentă cu celelalte discipline în planurile cadru de învățământ, oferă o evaluare corectă (de dorit, autentică), în termeni de proces, Educației religioase.

\section{BIBLIOGRAFIE SELECTIVĂ:}

Antonescu, G. G. (1923). Din problemele pedagogiei moderne. București: Editura Cartea românească.

Ausubel, D., Robinson, F. (1981). Învățtarea în Școală. București: Editura Didactică și Pedagogică.

Bocoș, M. (2008). Teoria și Metodologia Instruirii. Teoria și Metodologia Evaluării. București: Paralela 45.

Bulacu, Părintele M. (2009). Pedagogia creștin-ortodoxă. Constanța: Editura Școala Brâncovenească.

Cucoș, C., Labăr A. (2008,a). Consecințe ale educației religioase asupra formării conduitelor tinerilor. Perspectiva beneficiarilor. În: BASILEIA, vol. I, nr. 1-2, p. 61-98.

Cucoș, C. (2008, b). Educația. Iubire, edificare, desăvârșire. Iași: Editura Polirom.

Lawton, D. Evaluarea conținutului unui curriculum, În: D'Hainaut (coord.), trad. Leon Topa.

Lazăr, E. (2015). Evaluarea formativă. Un demers aplicativ în educația religioasă, București: Editura Universitară.

Levy, A. (2003). Enjeux sociaux occultés de l'évaluation, În: Penser l'evenement, Pour une psyhologie critique. http//www.pedagopsy.eu/

Manolescu, M. (2004). Activitatea evaluativă între cogniție și metacogniție. București: Editura Meteor.

Manolescu, M. (2010). Teoria și metodologia evaluării. București: Editura Universitară.

Mațăuan, G. Metode de evaluare a programelor sociale, În: Revista Calitatea vieții, nr. 1-2/1995. 
Memelis, G. (2012). Statutul actual al disciplinei religie - o analiză critică, În Dilema veche, anul IX, nr. 455, din 01-07 noiembrie 2012.

Opriș, M., Opriș D., Bocoș, M. (2004). Cercetarea pedagogică în domeniul educației religioase. Alba Iulia: Editura Reîntregirea.

Timiș, V. (2003). Evaluarea, factor de reglare și optimizare a educației religioase. Cluj-Napoca: Editura Renașterea.

Emil Lazăr este lector universitar doctor în cadrul Departamentului Comunicare, Jurnalism și Științe ale Educației, Facultatea de Litere, Universitatea din Craiova. Este preocupat de aspectul apreciativ-calitativ al evaluării școlare și de specificul evaluării în domeniul afectiv (cu aplicație în educația religioasă).

lazaremile@gmail.com 